\title{
Jurist-Diction
}

Volume 3 No. 5, September 2020

\section{Perlindungan Hak Cipta Atas Suara Komentator Dalam Turnamen DOTA 2}

\author{
R. Vicky Bayu Setyawan Putra P. \\ vickybayuu@gmail.com \\ Universitas Airlangga
}

How to cite:

R. Vicky Bayu Setyawan Putra

P., 'Perlindungan Hak Cipta

Atas Suara Komentator Dalam

Turnamen DOTA 2' (2020) Vol.

3 No. 5 Jurist-Diction.

Histori artikel:

Submit 15 Mei 2020;

Diterima 14 Agustus 2020;

Diterbitkan 1 September 2020.

DOI:

10.20473/jd.v3i5.21982

\begin{abstract}
Abstrak
Ciptaan dalam bentuk suara tidak diatur secara jelas apakah termasuk bentuk ciptaan yang dapat dilindungi oleh hak cipta menurut ketentuan yang ada di dalam Undang-Undang Nomor 28 Tahun 2014 Tentang Hak Cipta. Hal ini berimbas kepada suara komentator yang ada di dalam turnamen game DOTA 2 yang tidak menemukan kejelasan apakah termasuk ciptaan yang dapat dilindungi oleh Hak Cipta. Valve Corporation sebagai pemilik dari game DOTA 2 mengambil kesempatan dari hal tersebut dan memperjualbelikan suara komentator tanpa sepengetahuan dari komentator yang diambil suaranya tersebut. Valve Corporation yang memperjualbelikan suara tersebut mempunyai peluang unuk dikatakan sebagai pelanggaran di dalam bidang Hak Cipta. Di dalam skripsi ini menggunakan metode penulisan doctrinal research yakni dengan mengacu kepada bahan hukum primer dan sekunder seperti peraturan perundang-undangan. Skripsi ini akan membahas suara komentator dari segi perlindungan Hak Cipta dan akan menganalisis apakah kegiatan jual beli yang dilakukan oleh Valve Corporation termasuk pelanggaran Hak Cipta serta metode penyelesaian sengketa di bidang Hak Cipta.

Kata Kunci: Hak Cipta; Suara Komentator; Video Game.
\end{abstract}

\section{Pendahuluan}

Di zaman yang modern ini, perkembangan teknologi sangatlah pesat, termasuk perkembangan di dunia industri video game. Video game adalah permainan yang memanfaatkan teknologi visual dengan cara menampilkan gambar pada layar platform dan pemain bisa mengendalikan game itu secara langsung lewat konsol yang digunakan dan dapat dimainkan secara single player maupun multiplayer. Dunia industri video game menjadi ladang yang menjanjikan bagi para developer dan distributor game seperti Steam dan juga Riot Games dikarenakan semakin majunya teknologi membuat banyak orang dapat membeli perangkat komputer 
ataupun smartphone dengan harga yang cukup murah. ${ }^{1}$

Video game diminati semua kalangan mulai dari anak-anak hingga orang dewasa. Video game juga terdapat di beberapa perangkat salah satunya adalah lewat smartphone dan juga komputer. Besarnya minat seseorang untuk bermain video game tidak lepas dari kepuasan yang didapat dari bermain video game itu sendiri, salah satunya dikarenakan di dalam dunia video game saat ini banyak dijual item di dalam game yang dapat dibeli oleh para pemain dengan menggunakan uang elektronik seperti steam wallet code yang ada pada Steam dan juga $v$-bucks yang ada di dalam game Fortnite. ${ }^{2}$ Uang elektronik didapat dengan membeli menggunakan uang asli yang harganya mengikuti nilai tukar mata uang negara pembeli dengan Amerika. Negara Amerika menjadi pusat pertukaran uang elektronik video game dikarenakan hampir seluruh perusahaan developer dan distributor video game berasal dari negeri yang memiliki julukan paman sam tersebut.

Barang yang dijual di dalam video game cukup bervariasi mulai dari suara, kostum, stiker, dan wallpaper. Item yang dijual di dalam video game dapat memberi rasa senang atau kepuasan tersendiri kepada pembeli, contohnya kostum yang dijual di dalam game DOTA 2 dapat memperindah hero yang dipakai pada saat bermain dan dengan kostum itu maka hero tiap pemain akan menjadi berbeda daripada pemain yang lainnya, semakin mahal harga kostumnya maka hero yang dipakai tersebut akan menjadi pusat perhatian dan memiliki nilai prestige tersendiri. Salah satu transaksi item antar pemain DOTA 2 pernah mencapai angka yang fantastis setara harga mobil mewah dan majalah Forbes pernah meliput kejadian tersebut. Transaksi tersebut terjadi pada tahun 2013 antara pemain Brazil dengan nickname PAADA yang mempunyai tim game bernama PAIN GAMING dan pemain dari Cina yang tidak ingin disebutkan identitasnya. Item di dalam game yang diperjualbelikan adalah sebuah courier yang memiliki efek langka,

\footnotetext{
${ }^{1}$ Pladidus Santoso, 'Untungkan Publisher Besar, Steam Usung Sistem Bagi Hasil Baru', (jagatplay 2018), <https://jagatplay.com/2018/12/news/untungkan-publisher-besar-steam-usungsistem-bagi-hasil-baru $\geq$, accessed 15 Agustus 2019.

2 Ridwan Syahran, 'Ketergantungan Online Game dan Penanganannya' (2015) 1 Jurnal Psikologi Pendidikan dan Konseling .[85].
} 
transaksi jual beli item tersebut mencapai angka USD 38.000 atau setara dengan Rp 500.000.000,00 (lima ratus juta rupiah). ${ }^{3}$

DOTA 2 adalah sebuah video game yang dikembangkan oleh Valve Corporation bekerjasama dengan Icefrog yang inti dari game tersebut ada 10 pemain yang dibagi menjadi 2 tim yang berisi 5 orang dan tiap orang mengendalikan satu hero yang ada di dalam game tersebut dan berusaha untuk menghancurkan markas lawan secepat mungkin dan mempertahankan markas dari serangan musuh sebaik mungkin. ${ }^{4}$

Dalam video game DOTA 2 terdapat beberapa jenis item di dalam game yang biasanya dijual secara langsung oleh pihak DOTA 2 atau ada juga yang diperjualbelikan lewat pasar komunitas yang disediakan oleh pihak Steam untuk para pemain agar bisa bertukar item dengan pemain lainnya, pihak Steam biasanya akan memungut pajak sebesar 15\% untuk tiap item yang diperjualbelikan di dalam komunitas pasar yang disediakan oleh pihak Steam tersebut.

DOTA 2 memliki item di dalam game yang diberi nama Battle Pass, dimana di dalam Battle Pass ini terdapat beberapa tingkatan-tingkatan yang bisa diraih dengan cara menjalankan misi yang ada di dalam game tersebut atau dengan cara membeli poin menggunakan uang elektronik yang disebut steam wallet code. Tiap tingkatan memiliki sebuah reward yang dapat diraih oleh para pemilik Battle Pass jika sudah mencapai tingkatan tersebut, beberapa contoh reward tersebut ada yang berupa suara khas komentator DOTA 2 atau yang biasa disebut shoutcaster, kostum hero yang langka, dan bahkan di level tertingginya mendapatkan sebuah reward miniatur patung asli lambang dari video game DOTA 2 yang dikirim langsung ke rumah tiap masing-masing pemilik Battle Pass yang sudah mencapai level tertinggi di Battle Pass tersebut. ${ }^{5}$

\footnotetext{
3 Nitronexos, '5 Item Termahal di DOTA 2', (gamebrott, 2018), <www.gamebrott.com/5item-termahal-di-DOTA-2-harganya-setara-mobil-mewah>, accessed 15 Agustus 2019.

4 Nanang Budi, 'Prediksi Kemenangan BOT DOTA 2 Menggunakan Metode Naive Bayes', Skripsi (Universitas Dian Nuswantoro 2017).[3].

5 Valve Corporation, 'The International Battle Pass', (DOTA 2, 2019), <https://www. DOTA2.com/international/battlepass>, accessed 16 Agustus 2019.
} 
Namun sangat disayangkan pihak DOTA 2 mengambil suara para komentator yang membawakan acara turnamen tersebut tanpa ada izin kepada pihak penyelenggara turnamen dan bahkan si komentator yang suaranya dicatut juga tidak mengetahui jika suaranya diperjualbelikan oleh pihak DOTA 2, padahal penyelenggaraan turnamen DOTA 2 tidak selalu diadakan oleh pihak Valve Corporation sendiri sebagai pemilik video game DOTA 2. DOTA 2 mengambil keuntungan dengan menjual suara komentator tersebut dan menjadikannya sebagai reward di dalam Battle Pass yang dijual di dalam video game DOTA 2.

Pendapatan penjualan Battle Pass di dalam video game DOTA 2 dari tahun ke tahun selalu mengalami peningkatan dan bahkan di tahun 2019 ini penjualan Battle Pass sudah mencapai US\$ 33.579.314 atau setara dengan Rp 470.000.000.000 (empat ratus tujuh puluh milyar rupiah) itu bukan uang yang sedikit untuk perolehan satu tahun yang didapat dengan menjual item di dalam video game. Bahkan ada berita dari orang dalam di Valve Corporation mengatakan jika dalam 24 jam sejak peluncuran item Battle Pass, pihak DOTA 2 sudah mendapatkan uang sebesar US\$ 7.400.000 atau setara dengan Rp 106.000.000.000 (seratus enam milyar rupiah). ${ }^{6}$ Beberapa dari pendapatan tersebut juga akan dijadikan sebagai prize pool turnamen DOTA 2 yang diadakan oleh Valve Corporation setiap setahun sekali yang bertajuk The International. Bahkan digadang-gadang prize pool The International tahun ini akan menjadi hadiah turnamen e-sport terbesar sepanjang sejarah mengalahkan game Fortnite yang baru saja diadakan beberapa bulan lalu dan sempat heboh karena dimenangkan oleh remaja berusia 16 tahun. $^{7}$

Suara komentator di dalam turnamen DOTA 2 memiliki nilai ekonomi yang cukup besar dan sangat menjanjikan sehingga pihak DOTA 2 juga tidak membuang kesempatan ini untuk memperjualbelikan suara tersebut kepada pemain. Tetapi di

\footnotetext{
6 Dimas Aditya Jakti, 'Rekor Baru Prize Pool The International 2019',(pro.eslgaming, 2019) < https://pro.eslgaming.com/indonesia/DOTA2/2019/05/rekor-baru-prize-pool-the-international-2019/>, accessed 16 Agustus 2019.

7 Ido Limando, 'Jumlah Prize Pool DOTA 2 TI 2019 Sedikit Lagi akan Samai Jumlah dari Turnamen Fortnite World Cup', (gamebrott, 2019) <https:/gamebrott.com/jumlah-prize-poolDOTA-2-ti-2019-sedikit-lagi-akan-samai-jumlah-dari-turnamen-fortnite-world-cup>, accessed 16 Agustus 2019.
} 
sisi lain pihak DOTA 2 mengambil suara tersebut tanpa ada izin atau pemberitahuan kepada komentator yang suaranya diambil dan juga pihak penyelenggara turnamen DOTA 2 yang memiliki rekaman video turnamen tersebut, karena tidak semua turnamen DOTA 2 selalu diselenggarakan oleh pihak DOTA 2 itu sendiri.

Permasalahan ini cukup menarik untuk diteliti dan dianalisis karena di Indonesia sendiri juga banyak orang yang menjadi komentator turnamen DOTA 2 dan tidak menutup kemungkinan di masa depan suara komentator dari Indonesia akan diambil dan diperjualbelikan oleh pihak DOTA 2. Maka dari itu tulisan skripsi ini bisa dijadikan referensi penyelesaian masalah tersebut agar tidak terjadi kepada komentator turnamen DOTA 2 yang berasal dari Indonesia.

\section{Suara Komentator Sebagai Ciptaan}

Hak cipta memiliki beberapa persyaratan sebelum dilekatkan kepada suatu Ciptaan. Menurut Rahmi Jened suatu ciptaan dapat dilekatkan dengan hak cipta apabila memenuhi tiga persyaratan yaitu keaslian (originality), berdasarkan kemampuan pikiran atau imajinasi (creativity), serta yang terakhir yaitu suatu ciptaan harus memiliki bentuk yang khas (fixation). ${ }^{8}$ Akan tetapi, di dalam perkembangannya tiga persyaratan tersebut tidak selalu menjadi poin penting untuk menjadi persyaratan perolehan hak cipta kepada suatu Ciptaan dan tidak bersifat kumulatif.

Hak cipta di dalam Common Law System dan Civil Law System memiliki beberapa perbedaan salah satunya yaitu di dalam Civil Law System contoh negara penganutnya adalah negara Indonesia mengatakan bahwa suatu Ciptaan tidak harus mengandung unsur keaslian tetapi di dalam Common Law System suatu Ciptaan harus mengandung unsur keaslian. Di dalam UU No. 28 Tahun 2014 Tentang Hak Cipta syarat yang disebutkan secara eksplisit hanya satu syarat yaitu fiksasi. Jadi di dalam bab pembahasan ini akan dibahas mengenai persyaratan perolehan hak cipta atas suara komentator di dalam turnamen DOTA 2.

\footnotetext{
8 Rahmi Jened, Interface Hukum Kekayaan Intelektual dan Hukum Persaingan (Penyalahgunaan HKI) (RajaGrafindo Persada 2013).[79].
} 
Di dalam Pasal 1 angka 3 UU No. 28 Tahun 2014 Ciptaan adalah setiap hasil karya cipta di bidang ilmu pengetahuan, seni, dan sastra yang dihasilkan atas inspirasi, kemampuan, pikiran, imajinasi, kecekatan, keterampilan, atau keahlian yang diekspresikan dalam bentuk nyata. Jika dilihat dari pengertian Ciptaan yang baru di dalam UU No. 28 Tahun 2014 tidak disebutkan secara eksplisit bahwa suatu Ciptaan harus menunjukkan keasliannya atau dalam kata lain tidak diharuskan memenuhi unsur keaslian (originality).

Ciptaan menurut pengertian yang ada di dalam Pasal 1 angka 3 UU No. 19 Tahun 2002 Tentang Hak Cipta adalah hasil setiap karya Pencipta yang menunjukkan keasliannya dalam lapangan ilmu pengetahuan, seni, atau sastra. Jika dilihat dari pengertian yang ada di dalam pasal tersebut maka suatu Ciptaan yang dihasilkan oleh Pencipta harus memenuhi unsur keaslian (Originality), unsur keaslian yang dimaksud jika mengacu kepada pengertian yang ada di dalam Berne Convention keaslian adalah hal yang esensial agar suatu karya mendapatkan perlindungan hak cipta. Suatu Ciptaan yang tidak mengandung unsur keaslian maka tidak dapat dilindungi oleh hak cipta menurut UU tersebut.

Setelah UU No. 19 Tahun 2002 digantikan oleh UU No. 28 Tahun 2014 makna atau arti dari Ciptaan berubah drastis dan lebih bersifat luas pengertiannya. Di dalam Pasal 1 angka 3 UU No. 28 Tahun 2014 Ciptaan adalah setiap hasil karya cipta di bidang ilmu pengetahuan, seni, dan sastra yang dihasilkan atas inspirasi, kemampuan, pikiran, imajinasi, kecekatan, keterampilan, atau keahlian yang diekspresikan dalam bentuk nyata. Jika dilihat dari pengertian Ciptaan yang baru di dalam UU No. 28 Tahun 2014 tidak disebutkan secara eksplisit bahwa suatu Ciptaan harus menunjukkan keasliannya atau dalam kata lain tidak diharuskan memenuhi unsur keaslian (originality).

Suara komentator yang ada di dalam turnamen DOTA 2 jika dikaitkan dengan unsur keaslian (originality) maka suara komentator tersebut dapat dikategorikan sebagai Ciptaan yang asli karena para komentator berkata-kata secara spontan. Komentator yang satu dengan yang lainnya memiliki ciri khas suara dan pemilihan kata yang berbeda-beda dan perbedaan ini menjadikan nilai jual jasa para 
komentator satu sama lain menjadi berbeda. Komentator mungkin saja bisa meniru pemilihan kata yang sering dipakai oleh komentator lain tetapi hal itu tidak menutup kemungkinan suaranya berbeda. Perbedaan tersebut bisa dalam hal intonasi atau yang lainnya.

Menurut doktrin unsur keaslian (originality) yang menekankan bahwa suatu Ciptaan harus berwujud dan tertuang secara nyata, bukan hanya berbentuk ide atau pikiran dari Pencipta. Jika suara komentator dalam turnamen DOTA 2 dikaitkan dengan doktrin tersebut maka suara komentator tersebut dapat dikatakan memenuhi unsur keaslian karena sudah dalam bentuk nyata yaitu suara yang menjadi satu kesatuan dengan rekaman gambar yang memiliki hak terkait di dalamnya.

Suara komentator di dalam turnamen DOTA 2 jika dikaitkan dengan syarat unsur kreativitas (creativity) yang menekankan kepada suatu Ciptaan hanya dapat dilindungi oleh hak cipta jika dilekatkan kepada Penciptanya yaitu antara orang alamiah (natural person) dan bisa juga badan hukum (legal person), komputer atau binatang tidak masuk dalam kategori tersebut. Lalu jika dilihat sistem rekaman suara komentator yang menjadi satu kesatuan dengan rekaman gambar turnamen, perekaman suara dan gambar tersebut dilakukan secara otomatis oleh komputer namun jika dikaitkan dengan unur kreativitas maka hak cipta atas suara tersebut bukan melekat kepada komputer yang merekam suara dan video turnamen tersebut namun melekat kepada komentator yang suaranya sudah direkam oleh komputer tersebut. Komentator memnuhi persyaratan agar bisa diklasifikasikan sebagai Pencipta dan memenuhi unsur kreativitas (creativity).

Fiksasi menurut pengertian yang ada di dalam Pasal 1 angka 13 UU No. 28 Tahun 2014 adalah perekaman suara yang dapat didengar, perekaman gambar atau keduanya, yang dapat dilihat, didengar, digandakan, atau dikomunikasikan melalui perangkat apapun. Jika fiksasi diartikan sesuai dengan pengertian yang ada di undang-undang tersebut maka fiksasi hanya mencakup dua jenis Ciptaan yaitu suara dan rekaman gambar. Pengertian fiksasi yang ada di dalam undang-undang ini dikaitkan dengan suara komentator dalam turnamen DOTA 2 maka suara tersebut dapat digolongkan sebagai fiksasi yang dimaksud di dalam UU No. 28 Tahun 2014 
karena suara tersebut sudah berwujud dan dapat didengar, suara tersebut juga dapat digandakan melalui game DOTA 2 yang disediakan oleh Valve Corporation. Tetapi pasal tersebut hanya tentang hak terkait yang ada di dalam rekaman suara dan gambar dari turnamen tersebut, jika dikaitkan dengan hak cipta maka suara komentator lebih condong ke arah Pasal 40 ayat (1) huruf b UU No. 28 Tahun 2014 dan masuk ke dalam Ciptaan sejenis lainnya karena suara komentator belum dijelaskan secara eksplisit di dalam UU No. 28 Tahun 2014 tetapi di dalam Pasal 40 disebutkan beberapa poin ciptaan yang dapat dilindungi oleh hak cipta dan satusatunya poin yang mengarah ke suara hanya pada poin huruf $b$. Pada poin huruf $d$ ada lagu dan/atau musik dengan atau tanpa teks tetapi suara komentator tidak dapat dikaitkan dengan poin huruf $d$ tersebut karena yang membedakan suara komentator dengan lagu dan musik pada poin huruf d adalah di dalam lagu dan musik ada nada tetapi di suara komentator hanyalah berisi suara yang lebih condong kepada ceramah, kuliah, dan pidato yang tidak memiliki unsur nada di dalamnya.

Perolehan hak cipta atas suara didapat jika suara tersebut sudah ada wujudnya berupa kompilasi suara atau cukup suara saja dan jika dilihat dari ketentuan yang ada di UU No. 28 Tahun 2014 tidak diberi minimal durasi suara dan tidak diberi durasi maksimal juga. Namun, di dalam Pasal 1 angka 13 UU No. 28 Tahun 2014 dijelaskan bahwa Fiksasi adalah perekaman suara yang dapat didengar, perekaman gambar atau keduanya yang dapat dilihat, didengar, digandakan, atau dikomunikasikan melalui perangkat apapun. Padahal jika kita lihat pengertian dari doktrin fiksasi yang sebenarnya adalah tentang suatu perwujudan yang nyata atau bentuk suatu ciptaan yang khas yang membedakannya dengan ciptaan yang lain. Pengertian fiksasi yang ada di dalam UU No. 28 Tahun 2014 sangat sempit dan menimbulkan kesalahan dalam interpretasi fiksasi dalam lingkup hak cipta.

Namun jika dilihat dari doktrin fiksasi yang sebenarnya maka pengertian fiksasi yang ada di dalam UU No. 28 Tahun 2014 dinilai sangatlah sempit dan menimbulkan kesalahan interpretasi. Padahal doktrin fiksasi sebagai prinsip utama di dalam perlindungan hak cipta dan bahkan satu-satunya syarat perolehan hak cipta yang ditulis secara eksplisit di dalam UU No. 28 Tahun 2014. Istilah fiksasi 
jika melihat di dalam Berne Convention mengacu kepada bentuk yang khas atau nyata dari suatu Ciptaan sebagai syarat untuk mendapatkan dan dapat dilekatkan dengan perlindungan hak cipta, bukan mengacu pada bentuknya saja seperti yang ditulis di dalam undang-undang yaitu rekaman suara dan gambar. Menurut Berne Convention fiksasi dapat diartikan sebagai tindakan perwujudan dari sebuah ide menjadi bentuk yang nyata (tangible form). ${ }^{9}$

Suara komentator dalam turnamen DOTA 2 memenuhi syarat unsur fiksasi karena suara komentator tersebut sudah diwujudkan dalam bentuk suara yang menjadi satu dengan rekaman gambar dan suara, tentu saja rekaman gambar tiap pertandingan pasti berbeda dan memiliki ciri khas tersendiri. Maka dari itu suara tersebut memenuhi syarat unsur fiksasi karena sudah berwujud dan bukan hanya sekedar ide saja.

\section{Pencipta dan Pemegang Hak Cipta Atas Suara Komentator}

Komentator adalah termasuk orang alamiah (natural person) yang dapat memperoleh dan memegang hak cipta. Jika dilihat dari Common Law System ataupun Civil Law System, Komentator dapat disebut sebagai pencipta pertama dan utama karena inti dari suara tersebut berasal dari suara Komentator yang membawakan acara pertandingan di turnamen tersebut.

Komentator ada yang bekerja secara pribadi dengan melakukan streaming di beberapa platform seperti Twitch, Youtube, dan masih banyak lagi. Ada juga komentator yang dipekerjakan untuk membawakan acara turnamen yang diselenggarakan oleh penyelenggara turnamen. Jadi ada dua jenis komentator yang ada di dalam turnamen DOTA 2 yaitu komentator yang bekerja dengan melakukan streaming secara pribadi dan komentator yang dipekerjakan oleh penyelenggara turnamen untuk membawakan acara turnamen tersebut.

9 Risa Amrikasari, 'Menyoal Penyempitan Doktrin Fiksasi Dalam UU Hak Cipta Terbaru', (Hukum Online, 2014), <https://www.hukumonline.com/berita/baca/lt5437a94407a6a/menyoalpenyempitan-doktrin-fiksasi-dalam-uu-hak-cipta-terbaru-broleh--risa-amrikasari--ss--mh/> accessed 11 November 2019. 
Terdapat beberapa penyelenggara turnamen game DOTA 2, mulai dari pemilik game DOTA 2 itu sendiri yaitu Valve Corporation, lalu ada beberapa perusahaan swasta seperti Beyond The Summit, Electronic Sports League, Epic Esports Events, dan masih banyak lagi. Penyelenggaraan turnamen game DOTA 2 tidak pernah diadakan oleh orang secara individu. Penyelenggara turnamen game DOTA 2 selalu perusahaan yang rata-rata berbadan hukum menurut ketentuan negara asal perusahaan tersebut.

Hubungan yang ada di antara penyelenggara turnamen dengan komentator adalah hubungan kerja dan menurut ketentuan yang ada di dalam UU No. 28 Tahun 2014 suatu ciptaan yang lahir dalam hubungan kerja bukan instansi pemerintah maka hak cipta dan hak terkait dimiliki oleh kedua belah pihak, namun jika hubungan kerja dalam instansi pemerintah maka yang dianggap sebagai Pencipta adalah instansi pemerintah itu sendiri. Dalam turnamen DOTA 2 yang bukan instansi pemerintah maka seharusnya Pencipta atas suara komentator dapat dikatakan adalah komentator itu sendiri, namun penyelenggara turnamen tetap memiliki hak terkait atas rekaman suara dan gambar turnamen tersebut yaitu terkait fonogram yang dijelaskan di Pasal 1 angka 14 UU No. 28 Tahun 2014. Kecuali diperjanjikan lain oleh para pihak di dalam kontrak kerja jika seluruh hak kekayaan intelektual yang timbul selama hubungan kerja dimiliki oleh penyelenggara turnamen maka komentator tidak memiliki hak cipta maupun hak terkait atas rekaman suara tersebut, hal ini dijelaskan di dalam Pasal 35 dan 36 UU No. 28 Tahun 2014.

Valve Corporation sebagai pencipta dan pengembang dari game DOTA 2 merasa memiliki segala unsur yang ada kaitannya dengan game buatannya tersebut, bahkan suara dan gambar dari beberapa turnamen yang diselenggarakan oleh beberapa perusahaan swasta juga dianggap sebagai hak kepemilikan dari Valve Corporation karena dianggap suara dan gambar dari penyelenggaraan turnamen game DOTA 2 milik mereka jadi secara otomatis segala hal yang menyangkut tentang game DOTA 2 akan menjadi hak dari Valve Corporation. Di dalam "Valve Corporation DOTA 2 Tournament License And Paid Spectator Service Agreement" 
dijelaskan bahwa segala hak kekayaan intelektual yang menyangkut DOTA 2 adalah milik Valve Corporation, tetapi tidak dijelaskan secara rinci bagaimana jika hak kekayaan intelektual timbul dari pihak lain yang memanfaatkan game DOTA 2 dalam hal ini menyelenggarakan turnamen game DOTA 2.

Berdasarkan pengertian Pencipta di dalam UU No. 28 Tahun 2014 maka dapat ditarik kesimpulan bahwa suatu Ciptaan dapat dikualifikasikan menjadi dua yaitu secara pribadi sendiri ataupun dihasilkan dengan bersama-sama meskipun dikerjakan secara sendiri-sendiri maupun bersama-sama. Maka suatu Ciptaan akan memiliki hak kepemilikan yang berbeda-beda dilihat dari Ciptaan tersebut dikerjakan sendiri atau dikerjakan oleh beberapa orang. Hak eksklusif yang timbul dari Ciptaan yang dikerjakan oleh beberapa orang akan menjadi kepemilikan bersama dan otomatis hak moral dan hak ekonomi tidak bisa dipisahkan dari masing-masing pribadi yang sudah ikut berkontribusi dalam membuat Ciptaan tersebut karena memiliki hak terkait satu sama lain, jadi setiap tindakan yang akan diambil terkait Ciptaan tersebut harus dilakukan dan disetujui bersama-sama kecuali diperjanjikan lain.

Hubungan Valve Corporation dengan penyelenggara turnamen adalah hubungan perjanjian lisensi sesuai dengan ketentuan yang ada di dalam "Valve Corporation DOTA 2 Tournament License And Paid Spectator Service Agreement". Di dalam perjanjian tersebut sudah dijelaskan poin-poin dan kedudukan para pihak, namun jika dibaca secara teliti kedudukan Valve Corporation sebagai pemilik dan pengembang game DOTA 2 sangatlah superior dan dapat menyalahgunakan ciptaan yang memiliki unsur hak kekayaan intelektual.

Penyelenggara turnamen dan Valve Corporation dapat melakukan transaksi jual beli rekaman suara dan gambar suatu pertandingan turnamen secara langsung tanpa diketahui oleh komentator yang suaranya berada dalam rekaman tersebut. Namun jika dalam perjanjian kerja antara komentator dan penyelenggara turnamen sudah ditekankan secara jelas bahwa segala hak kekayaan intelektual yang timbul adalah milik penyelenggara turnamen maka komentator tidak dapat menutut apapun termasuk dengan haknya mendapatkan royalti sesuai dengan ketentuan yang ada di dalam UU No. 28 Tahun 2014 Pasal 35 ayat (2). 
Hak cipta memang tidak wajib didaftarkan seperti hak kekayaan intelektual yang lainnya, tetapi mendaftarkan ciptaan dan melekatkan dengan hak cipta sangatlah penting karena sebagai bukti awal atau yang disebut prima facie evidence dari kepemilikan hak dari Pencipta atas ciptaannya tersebut. ${ }^{10}$

\section{Hak Eksklusif Atas Suara Komentator}

Hak eksklusif mengandung dua esensi hak di dalamnya yaitu hak ekonomi dan hak moral, hal ini disebutkan di dalam Pasal 4 UU No. 28 Tahun 2014. Pencipta memiliki hak moral untuk dicantumkan namanya di dalam Ciptaan dan merupakan hak dari Pencipta juga untuk melarang orang lain mengubah Ciptaannya. Hak eksklusif lainnya yang dimiliki oleh Pencipta adalah Pencipta dapat memberi izin kepada seseorang yang memiliki hak terkait dengan Ciptaannya, dapat berupa izin untuk mengubah Ciptaannya dan izin untuk mengeksploitasi Ciptaan tersebut, dengan cacatan sudah mendapat izin dari Pencipta baik secara tertulis maupun tidak tertulis.

Pencipta atau Pemegang hak cipta memiliki hak ekonomi untuk melakukan apapun terhadap Ciptaannya. Beberapa hal yang diperbolehkan diatur di dalam Pasal 9 ayat (1) UU No. 28 Tahun 2014 yaitu bebas untuk:
a. Penerbitan Ciptaan;
b. Penggandaan Ciptaan dalam segala bentuknya;
c. Penerjemahan Ciptaan;
d. Pengadaptasian, pengaransemenan, atau pentransformasian Ciptaan;
e. Pendistribusian Ciptaan atau salinannya;
f. Pertunjukan Ciptaan;
g. Pengumuman Ciptaan;
h. Komunikasi Ciptaan; dan
i. Penyewaan Ciptaan.

Di dalam ketentuan yang ada di ayat selanjutnya yaitu ayat (2) diatur bahwa setiap orang yang melaksanakan hak ekonomi sebagaimana dimaksud pada ayat (1) wajib mendapatkan izin Pencipta atau Pemegang hak cipta. Selanjutnya di ayat (3) diatur bahwa orang yang tidak memiliki izin dari Pencipta atau Pemegang hak cipta dilarang melaksanakan hak ekonomi seperti yang disebutkan pada ayat (1).

\footnotetext{
${ }^{10}$ Rahmi Jened, Hukum Hak Cipta (Copyrighy Law) (Citra AdityaBakti 2014).[104].
} 
Hak moral memiliki dua hak penting di dalamnya, yaitu hak atribusi dan hak integritas. Hak atribusi mengharuskan identitas Pencipta dilekatkan pada Ciptaan yang dihasilkannya, baik dengan nama sendiri maupun nama samaran. Tetapi Pencipta juga memiliki hak untuk meniadakan identitas dirinya dan membiarkan hasil Ciptaannya bestatus anonim atau tanpa nama. Hak atribusi bertujuan untuk mencegah kesalahan identifikasi Pencipta dari suatu Ciptaan dan mencegah pengklaiman Ciptaan yang dilakukan oleh orang lain selain dari Pencipta asli. Hak integritas adalah citra pribadi dan reputasi yang melekat pada diri Pencipta. Tujuan hak integritas adalah melindungi suatu Ciptaan agar judul Ciptaannya tidak dapat dirusak, dipotong, atau dilakukan perubahan lainnya tanpa izin dari Pencipta asli.

Suara komentator dalam turnamen game DOTA 2 juga memiliki hak eksklusif di dalamnya yang dipegang oleh Pencipta dan Pemegang hak cipta atas suara tersebut. Hak eksklusif yang dimaksud adalah hak moral dan hak ekonomi yang ada di dalam Ciptaan suara tersebut. Hak moral yang dimaksud adalah hak pencipta untuk dicantumkan namanya di dalam Ciptaan, dalam kasus ini nama komentator yang diambil suaranya oleh Valve Corporation untuk diperjualbelikan harus dicantumkan di dalam Battle Pass. Komentator juga memiliki hak untuk menjaga keutuhan atau keaslian dari Ciptaan suaranya tersebut dan Valve Corporation salah dalam hal ini karena memotong suara tersebut tanpa ada diskusi dan komunikasi dengan komentator yang namanya dicatut dan penyelenggara turnamen yang memiliki dan menyimpan suara dan gambar turnamen yang mereka selenggarakan.

Dalam suara tersebut juga ada hak ekonomi di dalamnya, hak ekonomi yang dimaksud adalah hak untuk mendapatkan manfaat ekonomi dari Ciptaannya dan berhak untuk melakukan hal-hal yang dijelaskan di dalam Pasal 9 UU No. 28 Tahun 2014 seperti menerbitkan, menggandakan, mengadaptasi, dan menyewakan Ciptaan. Dalam kasus suara tersebut maka komentator dan penyelenggara turnamen memiliki hak ekonomi atas suara dan gambar termasuk untuk melakukan hal-hal yang diatur di dalam Pasal 9 UU No. 28 Tahun 2014. Pencipta dan Pemegang hak cipta dalam hal ini komentator dan penyelenggara turnamen harus sepakat dan setuju dalam melakukan sesuatu atas Ciptaan tersebut karena hak moral dan 
hak ekonomi harus dilakukan dan disetujui secara bersama-sama dan tidak dapat dilakukan oleh salah satu pihak saja, namun jika Ciptaan tersebut murni karena hasil karya Pencipta seorang diri maka Pencipta tidak perlu berdiskusi dan meminta persetujuan dari Pencipta atau Pemegang hak cipta lainnya.

\section{Kesimpulan}

Suara komentator merupakan ciptaan yang dapat dilindungi oleh hak cipta dan masuk ke dalam Pasal 40 ayat (1) huruf b tepatnya pada poin Ciptaan sejenis lainnya karena pada poin huruf $b$ tersebut adalah ciptaan-ciptaan yang mengandung unsur suara. Rekaman suara dan rekaman gambar adalah fiksasi dan fonogram yang merupakan hak terkait dari suatu ciptaan utama dalam hal ini adalah suara komentator. Suara komentator harus berbentuk nyata atau berwujud agar dapat dilindungi oleh hak cipta sesuai dengan doktrin dari fiksasi yang sebenarnya. Untuk mengetahui Pencipta dan pemegang hak cipta atas suara komentator harus melihat perjanjian kerja yang dibuat antara komentator dan penyelenggara turnamen serta perjanjian atau hubungan antara penyelenggara turnamen dengan Valve Corporation.

\section{Daftar Bacaan}

\section{Buku}

Rahmi Jened, Interface Hukum Kekayaan Intelektual dan Hukum Persaingan (Penyalahgunaan HKI) (RajaGrafindo Persada 2013).

Rahmi Jened, Hukum Hak Cipta (Copyright Law) (Citra AdityaBakti 2014).

\section{Jurnal}

Ridwan Syahran, 'Ketergantungan Online Game dan Penanganannya' (2015) 1 Jurnal Psikologi Pendidikan dan Konseling.

\section{Makalah}

Nanang Budi, "Prediksi Kemenangan BOT DOTA 2 Menggunakan Metode Naive Bayes", Skripsi Prodi Teknik Informatika Universitas Dian Nuswantoro (Universitas Dian Nuswantoro 2017). 


\section{Laman}

Pladidus Santoso, 'Untungkan Publisher Besar, Steam Usung Sistem Bagi Hasil Baru', (jagat play, 2018), <https://jagatplay.com/2018/12/news/untungkanpublisher-besar-steam-usung-sistem-bagi-hasil-baru/>, accessed 15 Agustus 2019.

Nitronexos, '5 Item Termahal di DOTA 2', (gamebrott, 2018), <www.gamebrott. com/5-item-termahal-di-DOTA-2-harganya-setara-mobil-mewah $>$, accessed 15 Agustus 2019.

Valve Corporation, 'The International Battle Pass', (DOTA 2, 2019), <https://www. DOTA2.com/international/battlepass>, accessed 16 Agustus 2019.

Dimas Aditya Jakti, 'Rekor Baru Prize Pool The International 2019',(pro.eslgaming, 2019) <https://pro.eslgaming.com/indonesia/DOTA2/2019/05/rekor-baruprize-pool-the-international-2019/>, accessed 16 Agustus 2019.

Ido Limando, 'Jumlah Prize Pool DOTA 2 TI 2019 Sedikit Lagi akan Samai Jumlah dari Turnamen Fortnite World Cup', (gamebrott, 2019) <https:/gamebrott. com/jumlah-prize-pool-DOTA-2-ti-2019-sedikit-lagi-akan-samai-jumlahdari-turnamen-fortnite-world-cup>, accessed 16 Agustus 2019.

Risa Amrikasari, 'Menyoal Penyempitan Doktrin Fiksasi Dalam UU Hak Cipta Terbaru', (Hukum Online, 2014), <https://www.hukumonline.com/berita/ baca/lt5437a94407a6a/menyoal-penyempitan-doktrin-fiksasi-dalam-uu-hakcipta-terbaru-broleh--risa-amrikasari--ss--mh/> accessed 11 November 2019.

\section{Perundang-undangan}

Burgerlijk Wetboek, Staatsblad Tahun 1847 Nomor 23.

Berne Convention for the Protection of Literary and Artistic Works, 1971.

Agreement on Trade-Related aspect of Intellectual Property Rights (TRIPs), 1994.

Undang-Undang Nomor 19 Tahun 2002 Tentang Hak Cipta (Lembaran Negara Tahun 2002 Nomor 85, Tambahan Lembaran Negara Nomor 4220).

Undang-Undang Nomor 28 Tahun 2014 Tentang Hak Cipta (Lembaran Negara Tahun 2014 Nomor 266, Tambahan Lembaran Negara Nomor 5599). 
R. Vicky Bayu: Perlindungan Hak Cipta

--halaman ini sengaja dibiarkan kosong-- 